\title{
Factors affecting adoption of improved farm practices by the farmers of Northern Bangladesh
}

\author{
K. S. Farid*, N. Z. Tanny and P. K. Sarma ${ }^{1}$ \\ Department of Rural Sociology and ${ }^{1}$ Bangladesh Agricultural University Research System, Bangladesh Agricultural \\ University, Mymensingh-2202, Bangladesh, *E-mail: ksfarid@gmail.com
}

\begin{abstract}
The present research examined the extent of adoption of improved farm practices by the farmers of Northern Bangladesh and determined the influencing factors for adopting these practices. This study was carried out in purposively selected Parbatipur upazila of Dinajpur district and Sherpur upazila of Bogra district as a representative of the northern Bangladesh. Data were collected from randomly selected 218 farmers through pre-tested interview schedule. Various descriptive and inferential statistical techniques were applied for getting meaningful results. Findings portray that most of the respondents belong to middle age group with a mean age of 47.02 years. The highest 37.2 percent of the respondents completed secondary level of education. Agriculture is the primary occupation of 89 percent of the respondents. The farmers have very low level of participation in various organizations. Contact with various communication media is very low for Sherpur compared to Parbatipur. The farm practices adopted mainly by the farmers are modern varieties, line sowing, power tiller, optimum tillage, balanced fertilizer, STW/DTW, IPM, balanced irrigation, rice weeder, sprayer and threasure. Among all practices, 'power tiller' adoption is the highest and 'line showing' is the lowest. Mean adoption score is 70.60. Results of multiple regression model indicates that communication score, total cultivable land, and socio-economic score have significant positive relationship, and total land area affected due to drought has significant negative relationship with adoption of improved farm practices by the farmers. Moreover, logistic regression model portrays that technology adoption is 1.49 times lower for Sherpur compared to Parbatipur. Finally, we can say that socio-economic factors influencing adoption of improved farm practices may be taken into consideration while accelerating the face of technology adoption under farming system.
\end{abstract}

Keywords: Farm practice, Adoption, Factors, Farmers, Bangladesh

\section{Introduction}

The continued changing pattern of climate give rise the necessity of adopting improved farming practices as farming sector is more susceptible to this change (Matata et al., 2010). Climate change introduces uncertainties in the livelihoods of communities having higher dependence on weather and climate (AlHassan and Poulton, 2009; Athula and Scarborough, 2011). It is becoming a threat towards world community through increasing temperatures, reduced precipitation, frequent droughts and scarcity of water (Adger et al., 2003; IPCC, 2007). The basic elements of food production such as soil, water and biodiversity are negatively affected by climate change (FAO, 2009). Farmers have therefore been modifying their farming practices to better adapt to the changing climate. But the traditional coping mechanisms are not sufficient for dealing with medium to long-term impacts of climate change (FAO, 2009). So, innovation of modern technologies is essential to mitigate the climate change adaptation (Clements et al., 2011). It is also important to understand how and when these technologies are used by farmers and with what impacts (Doss, 2006). An understanding of the factors that influence the adoption of an innovation is therefore important in the process of technology development and dissemination.

As a low lying downstream riparian country, Bangladesh is one of the most climate vulnerable countries in the world. The northern part is adversely affected by climate variable particularly drought. Improved farm practices in northern Bangladesh are therefore needed to become more available to improve the livelihoods of farmers. Several technologies and practices are available for smallholder farmers in northern Bangladesh to enable them better adapt to the effects of climate change. It however appears these technologies and practices have not been comprehensively documented in the climate change and technology adoption literature in Bangladesh. Technologies necessary to mitigate with climate shock in agriculture encompass a wide range of activities involve in agricultural practices that will need to be evaluated and prioritized. Examples include modifying planting times and switching to varieties resistant to heat and drought (Phiri and Saka, 2008); developing and adopting new cultivars (Eckhardt et al., 2009); changing the farm portfolio of crops and livestock (Howden et al., 2007); improving soil and water 
management (Kurukulasuriya and Rosenthal, 2003); improving fertilizer use and increasing irrigation (Howden et al., 2007); increasing labour or livestock input per hectare to increase productivity (Mortimore and Adams, 2001); increasing regional farm diversity (Reidsma and Ewert, 2008); and shifting to nonfarm livelihoods (Morton, 2007). Besides ensuring smooth operation some practices may even have negative effect on variability in the short-run as farmers and agricultural systems adjust to the new practices that in the long run decrease vulnerability (Giller et al., 2009; McCarthy et al., 2011). So, linking farmers to new sources of information on technology will be important, but is equally important is deciding the potential factors of technology adoption at farm level that influence their decisions.

Several factors may have influence on the extent of adoption of farm practices such as characteristics of farm practice; the adopters; the change agent (extension worker, professional, etc.); and the socioeconomic, biological, and physical environment in which the technology take place. Socio-psychological trait of farmers also plays an important role in technology adoption. The age, education attainment, income, family size, tenure status, credit use, value system, and beliefs are usually positively related to adoption. From the existing literatures it is evident that adoption of technologies in farming practices is affected by certain factors (Ziervogel et al., 2005; Hansen et al., 2007; Salehin et al., 2009). The farmer's attitude towards change, land, sources of information, membership of farmer's organizations, educational level, farm income, farmer's exposure, are the important socio-economic factors influencing adoption of farm innovations (Rousan, 2007). Factors that trigger adoption of new technologies comprise of young and educated male farmers, higher income level, risk orientation and decision making ability of farmers (Feder and Slade, 1984). Factors limited adoption of technology includes conservative old men, illiterate, weak belief on ensure high yield of new technology etc. So, it is evident that farmers' use of technologies can be influenced by various socio-economic factors. It can be concluded so far, though a number of studies have been conducted across the world on technology adoption, but there is dearth of literature on the specific factors that influence adoption of improved farming practices, especially among farmers in northern Bangladesh. This is a gap that must be bridged if the problem of low technology adoption among farmers is to be addressed and agricultural productivity is to be improved. Therefore, there is a necessity to address the factors influencing technology adoption to face the adverse effects of climate properly. Owing to this necessity this paper is aimed at examining the socio-economic issues of technology adoption among the farmers of the northern region of Bangladesh, which is relatively vulnerable to climate change threat, especially to drought. The specific objectives are as follows:

I. To determine the status of adoption of improved farm practices by the farmers, and

II. To determine the influencing factors for adopting improved farm practices by the farmers

\section{Materials and Methods}

This study was carried out in Northern part of Bangladesh where crop production is adversely affected by climate change variables such as rainfall and temperature. Two upazilas namely Parbatipur under Dinajpur district and Sherpur under Bogra district were selected purposively for field investigation as selected sites fall under Northern region of Bangladesh and vulnerable to climate change particularly affected by drought (FAO, 2009). Then, one union from each upazila was selected randomly. These unions are Boro Chandipur of Parbatipur and Garidaha of Sherpur upazila. Then, four villages from each union, that is, total 8 villages namely Boro Chandipur, Chaitapara, Jharuardanga, and Kalikabaridanga from Boro Chandipur union and Ramnagar, Kanupur, Hatgari, and Bonga from Garidaha union were selected randomly. All the farmers of these eight villages are the population of the present study from which a total of 218 sample farmers, 108 from Parbatipur and 110 from Sherpur, were selected randomly taking approximately $10 \%$ and $15 \%$ of the population from each village, respectively. The complete sample design is portrayed in Table 1.

Data collection was carried out through interview survey based on a semi-structured interview schedule. A first draft of the interview schedule was designed according to the research objectives. Then, this interview schedule was pre-tested during pilot survey organized in the study area. Four focus group discussions with farmers and local key informants were also organized to get insights on the main driving forces determining the adoption of improved farm practices in the study area. The interview schedule was up-dated based on pilot survey and later on, used for primary data collection from the farmers. Various descriptive and inferential statistical techniques i.e. percentage, mean, cross-tabulation, Chi-square, regression analysis, logistic regression etc. were applied for getting meaningful results by using Statistical Packages for the Social Sciences (SPSS). 
Table 1. Sampling framework of the study

\begin{tabular}{|c|c|c|c|}
\hline Name of the district & Name of the upazila & Name of the village & No. of sample farmers \\
\hline \multirow[t]{4}{*}{ Dinajpur } & Parbatipur & Boro Chandipur & 33 \\
\hline & & Chaitapara & 30 \\
\hline & & Jharuardanga & 23 \\
\hline & & Kalikabaridanga & 22 \\
\hline Sub-total & & & 108 \\
\hline \multirow[t]{4}{*}{ Bogra } & Sherpur & Ramnagar & 40 \\
\hline & & Kanupur & 21 \\
\hline & & Hatgari & 30 \\
\hline & & Bonga & 19 \\
\hline Sub-total & & & 110 \\
\hline Total & & & 218 \\
\hline
\end{tabular}

Source: Field Survey, 2014

Adoption quotient, developed by Sengupta (1967) is the dependent variable used in this study. Adoption quotient for an individual farmer was calculated based on the adoption scores gained by the farmer for the adoption of improved farm practices. A total of 11 improved farm practices were used for calculation of the adoption quotient.

Adoption Quotient $=($ Total adoption scores gained by farmer/Maximum adoption score $) \times 100$

On the basis of the adoption quotient, farmers were classified into three categories for Chi-square analysis $)$ such as low adoption $=<($ Mean $-1 S D)$, medium adoption $=($ Mean $\pm 1 S D)$ and high adoption $=$ $>$ (Mean + 1SD); and two categories for logistic regression analysis such as low adoption (<Mean) and high adoption ( $\geq$ Mean). For regression analysis, adoption quotient was used a continuous variable.

Regression analysis was used to determine the relative influence of independent variables in explaining the variation in the dependent variable. The equation is:

$\mathrm{Y}=\mathrm{a}+\mathrm{B}_{\mathrm{i}} \mathrm{X}_{\mathrm{i}}$; Where, $\mathrm{Y}=$ Adoption quotient; $\mathrm{a}=$ intercept; $\mathrm{B}_{\mathrm{i}}=$ regression coefficients and $\mathrm{X}_{\mathrm{i}}=$ Independent variables

Logistic regression model was used to determine the influencing factors for adopting technologies. The equation is:

$Y i=f\left(X_{i}\right)+e i ;$ Where, $Y=$ Farmers' adoption of improved farm practices (1 for high adoption and 0 for low adoption); and $\mathrm{X}_{\mathrm{i}}=$ Independent variables

\section{Results and Discussion}

\section{Socio-demographic and economic characteristics of the respondents}

Table 2 shows the distribution of respondents based on socio-demographic and economic characteristics. Almost 80 percent of the respondent belongs to the group ranges 31 years to 60 years with a mean age of 47.02 years. The highest 37.2 percent of the respondents completed secondary level of education and about 18 percent are illiterate. Agriculture is the primary occupation of 89 percent of the respondents followed by business 5 percent, service 4.6 percent, and other occupation 1.4 percent, respectively. In total, 29.4 percent of the farmers have had exposure to one or more training. On an average the farmers of the Parbatipur own about 276 decimals of cultivable land whereas; this share is very low for the farmers of Sherpur, owning only 93 decimals. Total annual average household income of the farmers of studied upazilas is about Tk. 167.5 thousand. On an average a household spend about Tk. 118.5 thousands yearly to bear all the family expenses. Despite earning more, however, the respondents of Parbatipur spend less than that of Sherpur. This is because of the higher living standard in Sherpur. 
Table 2. Distribution of respondents based on socio-demographic and economic characteristics

\begin{tabular}{|c|c|c|c|c|}
\hline Characteristics & Categories & Parbatipur $(\mathrm{N}=108)$ & Sherpur $(\mathrm{N}=110)$ & Total $(\mathrm{N}=218)$ \\
\hline \multirow[t]{4}{*}{ Age } & Up to 30 & $11(10.2)$ & $8(7.3)$ & $19(8.7)$ \\
\hline & $31-45$ & $44(40.7)$ & $43(39.1)$ & 87 (39.9) \\
\hline & $46-60$ & 37 (34.3) & $50(45.5)$ & 87 (39.9) \\
\hline & Above 60 & $16(14.8)$ & $9(8.2)$ & $25(11.5)$ \\
\hline \multirow[t]{5}{*}{ Level of education } & Illiterate & $17(15.7)$ & $22(20)$ & 39 (17.9) \\
\hline & Primary & $25(22.2)$ & $48(43.6)$ & $72(33)$ \\
\hline & Secondary & $48(44.4)$ & $33(30)$ & $81(37.2)$ \\
\hline & Higher secondary & $12(11.1)$ & $3(2.7)$ & $15(6.9)$ \\
\hline & Graduate & $7(6.5)$ & $4(3.6)$ & $11(5)$ \\
\hline \multirow[t]{4}{*}{ Occupation } & Agriculture & $91(84.3)$ & $103(93.9)$ & $194(89)$ \\
\hline & Business & $10(9.3)$ & $1(.9)$ & $11(5)$ \\
\hline & Service & $5(4.6)$ & $5(4.5)$ & $10(4.6)$ \\
\hline & Other & $2(1.9)$ & $1(.9)^{\prime}$ & $3(1.4)$ \\
\hline Training status & & $44(40.7)$ & $20(18.2)$ & $64(29.4)$ \\
\hline Land holdings (decimal) & & 276 & 93 & 184.5 \\
\hline Annual income ('000) & & 182 & 153 & 167.5 \\
\hline Annual expenditure ('000) & & 115 & 122 & 118.5 \\
\hline
\end{tabular}

Source: Field Survey, 2014

Note: Figures in the parentheses indicate percentage of each column total

The farmers of the study area have very low level of participation in various organizations. This is mostly true for the farmers of Sherpur upazila. Only about 15 percent of the farmers of Parbatipur are involved with farmers' cooperative society, whereas, the involvement of the farmers of Sherpur in this regard is zero. The percentage of farmers involved with $\mathrm{NGO}$ is about 60 for Parbatipur and 12 for Sherpur, respectively (Table 3 ).

Table 3. Percentage distribution of farmers on the basis of organizational participation

\begin{tabular}{l|cc}
\hline Name of the organization & Parbatipur & Sherpur \\
\hline Farmers' cooperative society & 14.8 & 0.0 \\
Mass education committee & 3.7 & 0.9 \\
NGO & 60.2 & 11.8 \\
School committee & 13.9 & 6.3 \\
Maszid committee & 22.2 & 14.5 \\
Bazar committee & 8.3 & 0.0 \\
Union Parishad & 2.8 & 0.0 \\
\hline
\end{tabular}

Source: Field Survey, 2014

Contact with various communication media like local leaders, dealers, and Upazila Agricultural Officer (UAO); participation in agricultural related meeting; and use of communication media is very low in Sherpur compared to Parbatipur, which is shown in Table 4.

Table 4. Communication exposure (percentage of respondent)

\begin{tabular}{lcc}
\hline Categories of personnel/media & Parbatipur & Sherpur \\
\hline Contact with local leaders & 89.8 & 36.4 \\
Contact with dealers & 89.8 & 66.4 \\
Contact with block supervisor & 77.8 & 49.1 \\
Contact with UAO & 43.5 & 2.7 \\
Participation in agricultural related meeting & 40.7 & 1.8 \\
Attending result demonstration meeting & 31.5 & 0.9 \\
Programmes in radio/TV & 88.9 & 70.9 \\
\hline
\end{tabular}

Source: Field Survey, 2014 


\section{Status of adopting improved farm practices}

The farm practices adopted mainly by the farmers of the study areas are modern varieties, line sowing, power tiller, optimum tillage, balanced fertilizer, STW/DTW, IPM, balanced irrigation, rice weeder, sprayer and threasure. Among all farm practices, 'power tiller' adoption is highest and 'line showing' is lowest in both upazilas. Significant variations are observed in the adoption of various farm practices between two areas except power tiller and rice weeder (Table 5), because of the variations in the socio-economic characteristics of the respondents of the two areas.

Table 5. Distribution of farmers adopting various improved farm practices

\begin{tabular}{lccc|c|c}
\hline Farm practices & Parbatipur & Sherpur & Total & Chi-square & Level of significance \\
\hline Modern varieties & $103(95.4)$ & $96(87.3)$ & $199(91.3)$ & 4.491 & 0.034 \\
Line sowing & $7(6.5)$ & $32(29.1)$ & $39(17.9)$ & 18.964 & 0.000 \\
Power tiller & $108(100)$ & $109(99.1)$ & $217(99.5)$ & 0.986 & 0.321 \\
Optimum tillage & $105(97.2)$ & $86(78.2)$ & $191(87.6)$ & 18.207 & 0.000 \\
Balanced fertilizer & $102(94.4)$ & $82(74.5)$ & $184(84.4)$ & 16.392 & 0.000 \\
STW/DTW & $86(79.6)$ & $109(99.1)$ & $195(89.4)$ & 21.870 & 0.000 \\
IPM & $73(67.6)$ & $11(10)$ & $84(38.5)$ & 76.317 & 0.000 \\
Balanced irrigation & $92(85.2)$ & $45(40.9)$ & $137(62.8)$ & 45.752 & 0.000 \\
Rice weeder & $49(45.4)$ & $55(50)$ & $104(47.7)$ & 0.468 & 0.494 \\
Sprayer & $101(93.5)$ & $109(99.1)$ & $210(96.3)$ & 4.787 & 0.029 \\
Threasure & $91(84.3)$ & $42(38.2)$ & $133(61)$ & 48.638 & 0.000 \\
\hline
\end{tabular}

Source: Field Survey, 2014

Note: Figures within parentheses indicate percentage

\section{Extent of adopting improved farm practices}

Extent of adopting improved farm practices is shown in Fig. 1. It is evident that mean adoption score is 70.6 with a standard deviation of 14.36. The figure indicates that adoption quotient is 70 for more than fifty farmers.

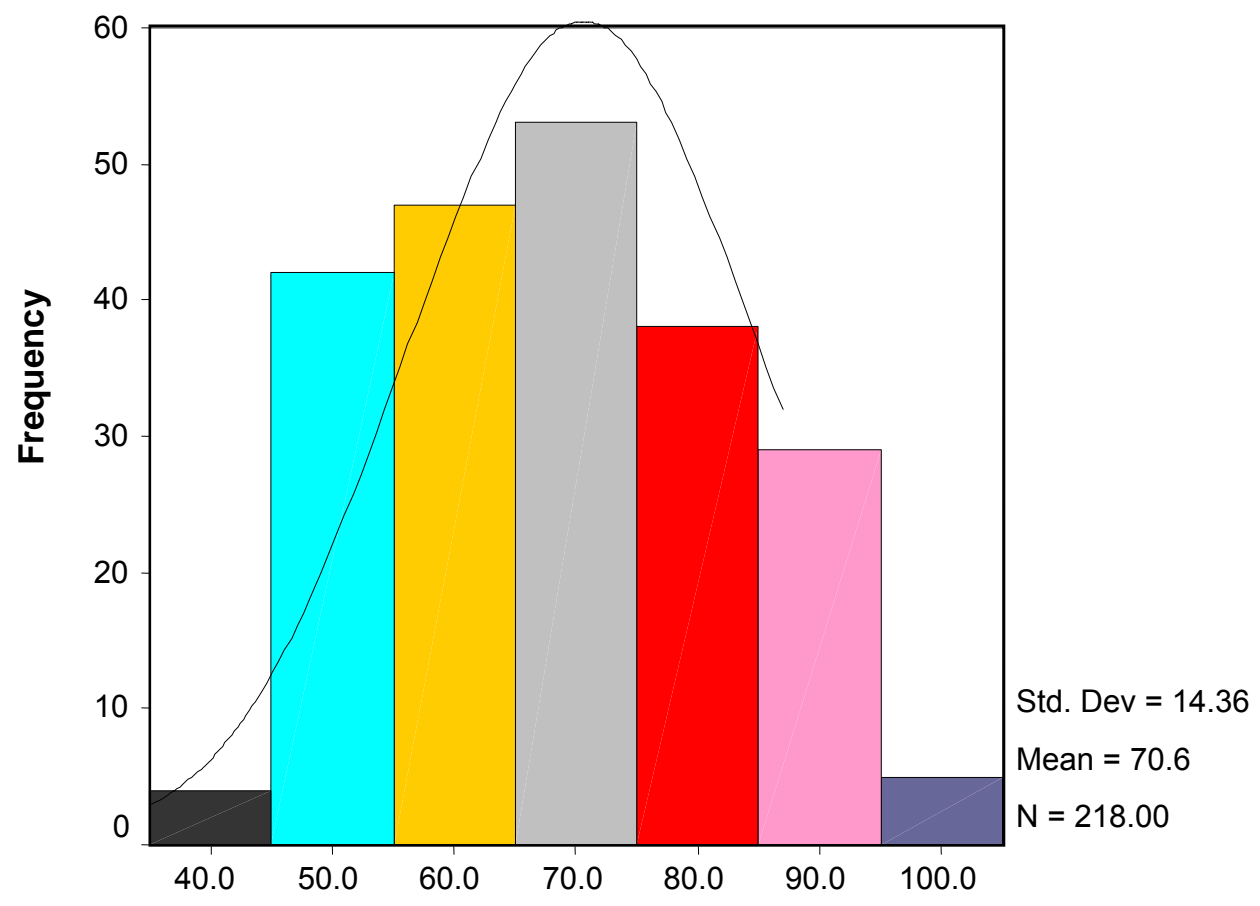

Adoption quotient

Fig. 1. Extent of adoption by the farmers 
Farmers of Parbatipur adopted more technologies than that of the farmers of Sherpur. About 69.6 percent farmers of Parbatipur are in 'high adoption' category, whereas, this percentage is only 30.4 for Sherpur (Table 6).

Table 6. Distribution of respondents based on two categories of adoption

\begin{tabular}{l|c|c|c|c}
\hline \multirow{2}{*}{ Adoption category } & \multicolumn{2}{|c|}{ Upzila } & & \multirow{2}{*}{ Chi-square } \\
\cline { 2 - 3 } & Parbatipur & Sherpur & Total & \\
\hline Low adoption & $21(22.6)$ & $72(77.40)$ & $93(100.0)$ & $47.161^{* * *}$ \\
High adoption & $87(69.6)$ & $38(30.4)$ & $125(100.0)$ & \\
\hline
\end{tabular}

Source: Field Survey, 2014

Note: Figures within parentheses indicate percent adoption

*** Significant at 0.05 level of probability

From the Table 7, it is clear that 79 percent and 21 percent of the respondents are from Parbatipur and Sherpur upazila among all high adoption category farmers.

Table 7. Distribution of respondents based on three categories of adoption

\begin{tabular}{l|cc|c|c}
\hline \multirow{2}{*}{ Adoption category } & \multicolumn{2}{|c|}{ Upzila } & Total & \multirow{2}{*}{ Chi-square } \\
\cline { 2 - 3 } & Parbatipur & Sherpur & & \\
\hline Low & $9(19.6)$ & $37(80.4)$ & $46(100.0)$ & \\
Medium & $42(42.0)$ & $58(58.0)$ & $100(100.0)$ & $44.089^{* * *}$ \\
High & $57(79.2)$ & $15(20.8)$ & $72(100.0)$ & \\
\hline
\end{tabular}

Source: Field Survey, 2014

Note: Figures within parentheses indicate percent adoption

*** Significant at 0.05 level of probability

\section{Factors influencing adoption of improved farm practices}

Table 8 presents the results of Chi-square test. It indicates that farmers' level of education, training status, communication score, and land holdings have strong positive relation with adoption of improved farm practices. On the other hand, age, involvement with cooperative society, and NGO affiliation do not have significant relation with adoption. The age of the respondents is found insignificant on adoption of farm practices of the selected respondent under study. This indicates that adoption of farm practices is not determined by the age of the respondents. Education level has a significant effect on adoption of technology, that is, rate of adoption is supposed to be higher with the increases of level of education. About 85 percent people are low adopter because they have no training. Communication score up to 5 indicates low adoption status, medium adoption are found among 48 percent people having communication score 6 to 10. Adoption of farm practices is high; about 39 percent for people who have communication score 6 to 10. Size of land holding has positive significant relationship with respect to adoption. In this study adoption of farm practices is low among the people who have low land (i.e., up to 99 decimal). Adoption rate is high, 40 percent among the people having 250 to 749 decimals of land.

The multiple regression analysis is employed to determine the relative influence of each independent variable in explaining the variation in the dependent variable. Table 9 reveals that 4 out of 7 selected independent variables such as, total land area affected, communication score, socio-economic score and total cultivable land have significant influence on extent of adoption. Surprisingly, total land area affected by drought is negatively related with farmers' adoption. The co-efficient of determination $\left(R^{2}\right)$ is 0.363 which implies that all the seven independent variables fitted together in the regression model could explain about $36.30 \%$ of the total variations in the extent of factors influencing adoption of the farmers. 
Table 8. Factors affecting improved farm practices adoption

\begin{tabular}{|c|c|c|c|c|c|c|}
\hline \multicolumn{2}{|r|}{ Factors } & \multicolumn{3}{|c|}{ Adoption category } & \multirow[t]{2}{*}{ Total } & \multirow[t]{2}{*}{ Chi-square } \\
\hline & & Low & Medium & High & & \\
\hline \multirow[t]{4}{*}{ Category of age (years) } & Up to 30 & 6.5 & 9.0 & 9.7 & 8.7 & 7.131 \\
\hline & $31-45$ & 52.2 & 40.0 & 31.9 & 39.9 & \\
\hline & $46-60$ & 37.0 & 40.0 & 41.7 & 39.9 & \\
\hline & Above 60 & 4.3 & 11.0 & 16.7 & 11.5 & \\
\hline \multirow[t]{4}{*}{ Level of education } & Illiterate & 17.4 & 21.0 & 13.9 & 17.9 & $20.853^{\star \star *}$ \\
\hline & Primary & 45.7 & 39.0 & 16.7 & 33.0 & \\
\hline & Secondary & 32.6 & 29.0 & 51.4 & 37.2 & \\
\hline & Higher secondary and above & 4.3 & 11.0 & 18.1 & 11.9 & \\
\hline \multirow[t]{3}{*}{ Training status (days) } & 0 (No training) & 84.8 & 76.0 & 54.2 & 70.6 & $15.353^{\star * *}$ \\
\hline & upto10 & 10.9 & 15.0 & 29.2 & 18.8 & \\
\hline & $10+$ & 4.3 & 9.0 & 16.7 & 10.6 & \\
\hline Categories of & Up to 5 & 63.0 & 32.0 & 13.9 & 32.6 & $63.346^{* * *}$ \\
\hline \multirow{3}{*}{ communication score } & $6-10$ & 32.6 & 48.0 & 30.6 & 39.0 & \\
\hline & $11-15$ & 4.3 & 18.0 & 31.9 & 19.7 & \\
\hline & $15+$ & 0.0 & 2.0 & 23.6 & 8.7 & \\
\hline \multirow{4}{*}{$\begin{array}{l}\text { Land holdings } \\
\text { (decimals) }\end{array}$} & Up to 99 & 50.0 & 38.0 & 15.3 & 33.0 & $30.801^{* * *}$ \\
\hline & $100-249$ & 37.0 & 34.0 & 33.3 & 34.4 & \\
\hline & $250-749$ & 13.0 & 26.0 & 38.9 & 27.5 & \\
\hline & $750+$ & 0.0 & 2.0 & 12.5 & 5.0 & \\
\hline \multirow[t]{2}{*}{ Farmers' cooperative } & Not involved & 97.8 & 92.0 & 90.3 & 92.7 & 2.470 \\
\hline & Involved & 2.2 & 8.0 & 9.7 & 7.3 & \\
\hline \multirow[t]{2}{*}{ NGO affiliation } & Not involved & 78.3 & 60.0 & 61.1 & 64.2 & 5.025 \\
\hline & Involved & 21.7 & 40.0 & 38.9 & 35.8 & \\
\hline
\end{tabular}

Source: Field Survey, 2014

*** Significant at 0.05 level of probability

Table 9. Result of multiple regression model

\begin{tabular}{l|c|c|c}
\hline Independent variables & $\mathrm{B}$ & $\mathrm{T}$ & $\mathrm{L}^{2}$ \\
\hline (Constant) & 5.137 & 8.222 & .000 \\
Age of the respondent & .014 & 1.760 & .080 \\
Year of schooling & .005 & .211 & .833 \\
Frequency of drought & .027 & .308 & .759 \\
Total land area affected & -.020 & -2.266 & .025 \\
Communication score & .125 & 5.544 & .000 \\
Socio-economic score & .049 & 1.965 & .050 \\
Total cultivable land & .001 & 2.985 & .003 \\
\hline
\end{tabular}

Dependent variable: Adoption quotient

*** Significant at 0.05 level of probability

The results of logistic regression model (Table 10) portray the fact that Sherpur upazila is a low adoption area and technology adoption is 1.49 times lower for Sherpur compared to Parbatipur. Communication score and total cultivable land is positive and significantly (at $5 \%$ level) related to farmers' adoption of improved farm practices. It indicates that adoption of farm practices increases with the increase in communication score and total cultivable land. This may be that large farmers are able to employ larger investment in improved practices.

Table 10. Result of Logistic regression model

\begin{tabular}{l|c|c|c|c|c}
\hline Independent variables (I) & $\begin{array}{c}\text { Coefficients } \\
(\mathrm{II})\end{array}$ & $\begin{array}{c}\text { Standard } \\
\text { error (III) }\end{array}$ & $\begin{array}{c}\text { Odds } \\
\text { ratio (IV) }\end{array}$ & $\begin{array}{c}\text { Coefficient from odd ratio } \\
(\mathrm{V})=(\mathrm{IV}-1)\end{array}$ & $\begin{array}{c}\text { Level of } \\
\text { Significance }\end{array}$ \\
\hline Upazila* $^{*}$ & -1.490 & 0.496 & 0.225 & -0.775 & 0.003 \\
Age & 0.017 & 0.015 & 1.017 & 0.017 & 0.277 \\
Level of education & -0.024 & 0.044 & 0.977 & -0.023 & 0.591 \\
NGO affiliation*** & -0.498 & 0.457 & 0.608 & -0.392 & 0.276 \\
Land area affected by drought & -0.018 & 0.016 & 0.982 & -0.008 & 0.251 \\
Communication score & 0.128 & 0.048 & 1.137 & 0.137 & 0.008 \\
Total cultivable land & 0.003 & 0.001 & 1.003 & 0.003 & 0.017 \\
Constant & -0.538 & 0.997 & 0.584 & -0.416 & 0.589 \\
\hline
\end{tabular}

Note: * Ref.: Parbatipur, ${ }^{* \star}$ Ref.: Higher secondary and above, ${ }^{* \star *}$ Ref.: Involved

Dependent variable: Adoption quotient 


\section{Conclusion}

Bangladesh is adversely affected by climate change and drought has become inevitable in Northern part of the country. The farmers have been using traditional and modern technologies in order to cope with the challenges of climate induced drought. Various practices were used by the farmers in response to altered farming resulting from experienced environmental degradation due to events associated with climate change. Power tiller was ranked as the first among adoption practices in order by percentage, while line showing was ranked as least adopted. This study sought to determine the factors that influence the adoption of climate related improved farm practices by the farmer. The empirical results explore that some of the indicators have either positive or negative impact on the adoption of improved farm practices. Several factors such as communication score and total cultivable land have positive effect on adoption of the farmers and total land area affected due to drought has negative effect on adoption of the farmers. Proper evaluation of these factors will help to further dissemination of technology in northern Bangladesh. This study represents a preliminary insight into understanding the factors influencing farmer's adoption of improved farm practices related to climate change. It widens the space for further in-depth research on socio-economic influences which can inform policy makers of Bangladesh how to shift in farming for ensuring agricultural development under increasingly adverse climatic conditions.

\section{References}

Adger, W.N., Huq, S., Brown, K., Conway, D., and Hulme, M. 2003. Adaptation to Climate Change in the Developing World. Progress in Development Studies, 3 (3), 179-195.

Al-Hassan, R., and Poulton, C. 2009. Agriculture and Social Protection in Ghana. Future Agricultures. Working Paper No. 009.

Athula, S., and Scarborough, H. 2011. Coping with Climatic Variability by Rain-fed Farmers in Dry Zone, Sri Lanka: Towards Understanding Adaptation to Climate Change. Australian Agricultural and Resource Economics Society (AARES), 55th Annual National Conference 8-11 February 2011, Melbourne, Victoria.

Clements, R., Haggar, J., Quezada, A., and Torres, J. 2011. Technologies for Climate Change Adaptation- Agriculture Sector. X. Zhu (Ed.). UNEP Rios Centre, Roskilde.

Doss, R.C. 2006. Analyzing Technology Adoption Using Micro Studies: Limitations, Challenges, and Opportunities for Improvement. J. Agri. Econ. 34, 207-219.

Eckhardt, N.A., Cominelli, E., Galbiati, M., and Tonelli, C. 2009. The Future of Science: Food and Water for Life. Plant Cell, 21, $368-372$.

Feder, G. and Slade R. 1984. The Acquisition of Information and the Adoption of New Technology. American J. Agri. Econ., 66, 312320.

Food and Agriculture Organisation (FAO). 2009. Profile for Climate Change, Rome, Italy. P.28.

Giller, K. E., Witter, E. M., Corbeels, and Tittonell, P. 2009. Conservation Agriculture and Smallholder Farming in Africa: The heretics' view. Field Crops Research, 114, 23-34.

Hansen, J., Baethgen, W., Osgood, D., Ceccato, P., and Ngugi, R.K. 2007. Innovations in Climate Risk Management: Protecting and Building Rural Livelihoods in a Variable and Changing Climate. J. Semi-Arid Trop. Agri. Res., 4 (1), 1-38.

Howden, S.M., Soussana, J., Tubiello, F.N., Chhetri, N., Dunlop, M., and Meinke, H. 2007. Adapting Agriculture to Climate Change Effects. Proceedings of the National Academy of Sciences of the United States of America, 104 (50), 19691-19696.

Intergovernmental Panel on Climate Change (IPCC). 2007. Climate Change 2007: Impacts, Adaptation, and Vulnerability. Contribution of Working Group II to the Fourth Assessment Report. Cambridge University Press, Cambridge, UK.

Kurukulasuriya, P. and Rosenthal, S. 2003. Climate Change and Agriculture: A Review of Impact and Adaptations. Paper No. 91 in Climate Change Series, Agriculture and Rural Development Department and Environment Department, World Bank, Washington, DC.

Mortimore, M.J. and Adams, W.M. 2001. Farmer Adaptation, Change and "Crisis" in the Sahel. Global Environmental Change, 11, 49-57.

Morton, J.F. 2007. The Impact of Climate Change on Smallholder and Subsistence Agriculture. Proceedings of the National Academy of Sciences of the United States of America, 104, 19680-19685.

Matata, P.Z, Ajay, O.C. Oduol, P.A., and Agumya, A. 2010. Socio-economic Factors Influencing Adoption of Improved Fallow Practices among Smallholder Farmers in Western Tanzania. African J. Agri. Res., 5(8), 818-823.

McCarthy, L., Lipper, L., and Branca, G. 2011. Climate Smart Agriculture: Smallholder Adoption and Implication for Climate Change Adaptation and Mitigation. FAO working paper, Draft.

Phiri, I.M.G., and Saka, A.R. 2008. The Impact of Changing Environmental Conditions on Vulnerable Communities in the Shire Valley, Southern Malawi. In C. Lee and T. Schaaf (eds.), The Future of Dry lands. 545, UNESCO.

Reidsma, P., and Frank, E. 2008. Regional Farm Diversity can Reduce Vulnerability of Food Production to Climate Change. Ecology and Society, 13 (1), 38.

Rousan, L.M. 2007. Factors Influencing Adoption of Improved Farm Practices among Women Farmers in Northern Jordan. American-Eurasian J. Agri. \& Env. Sci., 2 (3), 220-226.

Salehin, M.M., Kabir, M.S., Morshed, K.M., and Farid, K.S. 2009. Socioeconomic Changes of Farmers due to Adoption of Rice Production Technologies in Selected Areas of Sherpur district. J. Bangladesh Agri. Uni., 7(2), 335-341.

Sengupta, T. 1967. A Simple Adoption Scale for Farmers for High Yielding Varieties of Paddy. Indian J. Extn. Edu., 3, 107-115.

Ziervogel, G., Bithell, M., Washington, R., and Downing, T. 2005. Agent-based Social Simulation: A Method for Assessing the Impact of Seasonal Climate Forecasts among Smallholder Farmers. Agril. Systems, 83 (1), 1-26. 